\title{
STRATEGI BAURAN PEMASARAN (MARKETING MIX STRATEGY) DI PASARKITA PAMULANG
}

\author{
Arie Putra Benyamin \\ email : arie benyamin@yahoo.com
}

ABSTRAK

Penelitian ini bertujuan untuk mengetahui 1) Kondisi dan peluang Pasarkita untuk dapat ramai dan maju , 2 ) Implementasi Strategi Bauran Pemasaran (Marketing Mix Strategy) 3) Implementasi strategi pemasaran dari pengelola pasar dan para pedagang.

Penelitian ini menggunakan metode pengamatan dengan tekhnik survey ke lapangan dan melihat kondisi dan potensi pasar saat ini untuk menjadi bahan masukan dan evaluasi dari pelaku dan koordinator pasar sehingga dapat menjadi pasar yang ramai dan tersedianya beraneka ragam kebutuhan konsumen dan calon pembeli.

Berdasarkan hasil survey dilapangan, pengamatan dan analisis lingkungan pasar , potensi pasar cukup potensial dimana lokasi tempat (Place) terletak strategis dengan posisi pasarkita terletak di pusat kota Pamulang, terletak dipinggir jalan utama dan dilalui angkutan umum, lingkungan penduduk yang padat, Kampus, Pusat Perdagangan/Perkantoran dan Perumahan penduduk disekitar pasarkita sehingga potensi calon konsumen untuk memenuhi kebutuhan bahan pokok sehari- dapat terpenuhi dengan mudah dari berbagai akses, Tempat sarana Parkir yang luas merupakan daya tarik bagi calon konsumen yang mempunyai kendaraan mobil sehingga kenyamanan untuk berbelanja di pasarkita dapat terpenuhi.

Hasil penelitian melalui implementasi strategi pengembangan pasar melaui penetrasi pasar dan strategi pemamasara terpadu (Marketing Mix strategy) diharapkan dapat menjadi masukan untuk diimplementasikan kepada para pelaku pasar dan koordinator pasar di Pasarkita Pamulang.

Abstrac

1) Market conditions and opportunities to be complex and advanced, 2) Implementation of the Marketing Mix Strategy (3) Marketing Implementation Strategy from market managers and traders..

This research uses observational methods with survey techniques to the field and looks at the current market conditions and potential to be input and evaluation material from market actors and coordinators so that it can become a crowded market and the availability of diverse needs of consumers and prospective buyers.

Based on the survey results in the field, observing and analyzing the market environment, the potential of the market is quite potential where the location of the place is strategically located in the market position located in the center of Pamulang, located on the main road and passed by public transportation, densely populated environment, Campus, Trade Center / Office and Housing residents around the market so that the potential of potential consumers to meet the basic needs of a day - can be easily fulfilled from various accesses, Large parking facilities are an attraction for prospective customers who have car vehicles so that the convenience for shopping in the market can be fulfilled.

The results of the research through the implementation of market development strategies through market penetration and integrated marketing strategies (Marketing Mix 
strategy) are expected to be input to be implemented for market participants and market coordinators in Pasarkita Pamulang.

Keywords: Perform marketing mix strategy (Marketing Mix Strategy) to enliven Pasarkita Pamulang.

\section{A. Pendahuluan}

Pasarkita Pamulang merupakan salah satu pasar yang keberadaannya sejak tahun 2012 sudah hampir 7 tahun beroperasi, Pasar yang dibangun oleh Developer P.T. Pahala Alam Progress dengan konsep Pasar Modern dengan design dan penataan lay out seperti lazimnya Pasar Modern yang ada di Jabodetabek. Bagian pasar terdiri dari lay out Ruko, Toko, Kios dan Lapak-lapak yang lokasinya sudah diposisikan sesuai design yang dibuat peruntukan konsep Pasar Modern yang berada di pusat kota dan strategis. Pada saat launching Pasarkita Pamulang banyak diminati masyarakat yang ingin buka usaha, mengembangkan usaha, dan beberapa pembeli untuk Investasi dibidang property terutama pembeli Ruko dan Toko dilingkungan Pasarkita Pamulang. Pada saat pembelian perdana umumnya para pemilik mempunyai harapan dapat berusaha dengan melihat perkembangan pasar modern disekitarnya seperti : Pasar Modern BSD, Pasar Modern Bintaro yang relatif ramai dan dapat meningkatkan nilai investasi.

Letak strategis dari pasarkita merupakan salah satu daya tarik dari calon pengusaha/ pedagang dan investor untuk membeli property baik secara cash dan kredit perbankan.

Kondisi dan situasi Pasarkita saat ini masih jauh dari harapan para pedagang dan pemilik Ruko,Toko, Kios dan lapak yang sudah 7 tahun beroperasi untuk berusaha dan berdagang, namun oleh karena masih sepinya pengunjung pembeli yang masuk untuk berbelanja di Pasarkita, mengakibatkan banyak para pedagang yang enggan untuk membuka usaha di Ruko, Toko, kios dan lapak yang berdasarkan pengamatan masih banyak yang tutup dan tidak beroperasi untuk berdagang. Kalau melihat dari kebutuhan konsumen sehari-hari untuk berbelanja kebutuhan pokok berupa sandang, pangan dan kebutuhan bahan baku masak para ibu-ibu yang setiap harinya perlu kepasar. Mengamati dari potensi pasar, lingkungan, dan lokasi yang strategis dan melihat kondisi saat ini dari Pasarkita Pamulang, maka penulis tertarik memilih obyek penelitian di Pasarkita Pamulang .

Pasarkita pamulang selama ini dikelola langsung oleh Developer PT.Pahala Alam Progress dan menjual kepada pemilik Ruko, Toko dan Kios, namun beberapa tahun ini kurang perhatian dan terkesan tidak ada upaya untuk memajukan Pasarkita Pamulang. Sedangkan lapak-lapak, saat ini oleh Developer diserahkan dan dikelola Pemda Tangerang Selatan. Oleh karena kondisi sampai saat ini masih sepi dari pengunjung ke pasarkita, banyak pemilik kios yang belum beroperasi, sehingga hasilnya belum memenuhi harapan para pedagang. Salah satu kendala ramainya pasarkita adalah masih terdapat pasar tradisional yang terletak dilingkungan Perumahan Pamulang Permai , yaitu pasar Mandiri yang sebetulnya bukan peruntukan pasar tradisional dan dikelola secara illegal karena lokasi bukan tempat peruntukan Pasar, namun Pemda Tangerang Selatan belum dapat memindahkan para pedagangnya untuk mengisi lapak dan kios di Pasarkita Pamulang. Berdasarkan kondisi dan pengamatan penulis di Pasarkita Pamulang,

Vol. 2 No. 3 Juni 2019 
maka perlu dilakukan Strategi Pemasaran dan implementasinya, yaitu strategi bauran Pemasaran untuk mengetahui langkah-langkah dan implementasi strategi bagi pengelola pasar dan para pedagang agar sesuai harapan yang diinginkan, yaitu pasar menjadi ramai, pusat pasar modern dengan tersedianya kebutuhan sandang, pangan dan kebutuhan ibu rumah tangga dalam membeli bahan baku untuk memasak dirumah.

\section{B. Perumusan Masalah}

Berdasarkan pengamatan dan kondisi saat ini di Pasarkita Pamulang permasalahan yang dihadapi para pedagang dan pemilik Ruko, Toko, Kios dan pedagang di lapak-lapak, perumusan masalah sebagai berikut :

1. Bagaimana peran dari Developer P.T Pahala Alam Progress dan Pemda Tangerang Selatan melalui program pemasaran untuk meramaikan dan memajukan Pasarkita Pamulang?

2. Mengapa Pasarkita sampai saat ini belum banyak dikunjungi konsumen padahal lokasi strategis, potensi dan lingkungan mendukung ?

3. Bagaimana mengatasi permasalahan dan membuat konsep solusinya ?

\section{Tujuan Penelitian}

1. Untuk mengetahui Kondisi Pasarkita saat ini

2. Untuk mengetahui langkah-langkah program Pemasaran yang telah dan akan dilakukan

3. Untuk mencari solusi dan upaya implementasi strategi Pemasaran sesuai harapan para pedagang Pasarkita.

\section{Landasan Teori}

Pengertian Pemasaran menurut Philip Kotler : “ Kegiatan manusia yang diarahkan pada usaha untuk memuaskan keinginan (wants ) dan kebutuhan (needs )melalui proses pertukaran. "

Pasar adalah tempat bertemunya antara penjual dan pembeli untuk melakukan transaksi jual beli produk barang dan jasa.

Pemasar(penjual) adalah badan usaha bisnis, organisasi profit/nonprofit dan para pedagang/penjual retail.

Pembeli (pasar sasaran) adalah Pembeli yang ada dan pembeli potensial yang diharapkan akan datang ke pasar yang dituju.

Marketing Mix adalah bauran pemasaran yang dapat digunakan oleh Perusahaan untuk menciptakan penjualan sesuai dengan pasar sasaran yang dituju. Bauran tersebut adalah Produk (product), Harga (price), Distribusi (distribution)dan Promosi (promotion). Perusahaan harus menyelaraskan keempat bauran tersebut dalam usaha untuk mencapai tingkat penjualan yang diinginkan. Artinya jika pasar sasaran yang ingin dituju adalah kalangan atas yang memiliki duit, maka produk harus berkualitas dan bergengsi, harga harus premium, penampilan gerai eksklusif dan media promosi serta pesan yang ditampilkan juga menunjukan kelas atas.

Seiring dengan perubahan situasi persaingan bisnis, teknologi informasi dan tuntutan pelanggan, maka strategi bauran pemasaran harus disesuaikan dengan perubahan zaman yang berbisnis diera digital, on line dan e -Commerce. 
Strategi Pemasaran merupakan pernyataan yang memberi petunjuk tentang arah dan tujuan dari berbagai usaha penting untuk mencapai sasaran yang dikehendaki .

\section{E. Metodologi Penelitian}

Obyek dalam penelitian ini adalah Pasarkita Pamulang, Kotamadya Tangerang Selatan, Subyek penelitian kondisi fakta di Pasarkita, wawancara dengan para pedagang, pengelola pasar dan pengurus Perhimpunan Pedagang Pasarkita Pamulang.

Jenis Penelitian adalah Diskriftif asosiatif yang mengungkapkan secara fakta kondisi Pasarkita saat ini baik dari sisi pedagang kios, lapak, toko dan Ruko yang berada di pasarkita. Disamping itu dilakukan pengamatan ( Observasi ) keadaan pasarkita dari waktu kewaktu.

Metode pengumpulan data yang penulis gunakan adalah melalui Studi Pustaka (Library research) dan Studi lapangan (Field research) untuk memperoleh data dan informasi yang relevan, akurat dan reliable.

\section{F. Hasil dan Pembahasan}

Melihat kondisi dan perkembangan Pasarkita pamulang dapat diperoleh informasi sebagai berikut :

Sejak beroperasinya Pasarkita Pamulang pada tahun 2012, awalnya para pedagang dan pemilik kios, toko dan Ruko optimis dan mengharapkan prospek tempat usaha dan investasi yang menguntungkan dan mengharapkan banyak dikunjungi para calon konsumen untuk memenuhi kebutuhannya. Hal tersebut diyakini karena lokasi Pasarkita yang strategis dan dekat dengan perumahan penduduk sebagai pasar sasaran (Target Market), namun dari tahun ke tahun sampai saat ini kondisinya tidak sesuai harapan, karena setiap harinya bedasarkan pengamatan masih dalam kondisi sepi pengunjung dari calon konsumen yang diharapkan para pedagang.

Masih banyak terdapat lapak, kios, toko dan ruko yang saat ini kondisi tutup karena pemilik/ pedagang enggan membukanya karena memperhitungkan dari sisi belum banyaknya calon pembeli yang berkunjung ke Pasarkita Pamulang selain kemungkinan memperhitungkan "cost and benefit "

Pengelolaan lapak - lapak saat ini oleh Developer diserahkan kepada pengelola pasar dari Pemda Tangerang selatan dengan upaya agar menarik calon konsumen yang masih memanfaatkan pasar-pasar tradisional dan terletak dilokasi bukan pada tempatnya seperti Pasar Mandiri dekat Perumahan Pamulang Permai yang berada di jalan sekitarnya serta tidak ada / memperoleh izin pasar sesuai Perda dan pengelolaan Pemda Kota madya Pamulang. Permasalahan ini merupakan salah satu dari kondisi yang mengakibatkan kurang minatnya calon konsumen disekitar perumahan tersebut untuk berbelanja di pasarkita Pamulang yang hanya berjarak berkisar $1 \mathrm{Km}$ dari lokasi Pasarkita.

Konsep keberadaan dan dibangunnya Pasarkita Pamulang adalah memiliki lay out dan design seperti halnya konsep pasar di Pasar modern BSD dan Bintaro , dimana terletak ditempat strategis, dekat perumahan penduduk, mudahnya transportasi darat, dekat pusat pertokoan /perkantoran dan dekat dengan kampus Unpam. Hal ini menunjukan potensi pasar dalam menarik calon konsumen yang diharapkan sehingga dapat berkembang dan tumbuhnya usaha perdagangan serta tersedianya kebutuhan bahan pokok dan bahan baku untuk 
memasak terutama bagi para ibu-ibu dilingkungan untuk berbelanja sesuai harapan para pedagang.

Menganalisis permasalahan yang dihadapi para pedagang dan pemilik toko, kios dan ruko serta pedagang yang dilapak-lapak di Pasarkita Pamulang serta memberikan pencerahan dan solusi maka perlu pembahasan secara teori dan implementasi strategi Pemasaran, yaitu strategi bauran pemasaran.

Pasarkita Pamulang terdiri lokasi tempat usaha dalam bentuk Ruko $=21$ unit, Toko = 15 Unit, Kios = 256 unit dan dalam pasar terdapat 200 lapak untuk para pedagang retail (sayuran, perikanan, daging, bumbu dapur, buah, kuliner, makanan ringan dan pedagang lainnya)

Berdasarkan kondisi dan fakta tersebut diatas, dan pengamatan lingkungan pasarkita Pamulang perlu pembahasan mengenai implementasi Strategi Bauran Pemasaran (Marketing Mix Strategy) di Pasarkita.

Strategi bauran Pemasaran, ada 4 variabel yang biasa disebut $4 \mathrm{P}$, yaitu Produk (Product), Harga (Price), Tempat/Lokasi (Place) dan Promosi (Promotion).

\section{PRODUK (Product)}

Strategi Bauran pemasaan melalui Produk merupakan bagian yang penting, dimana Pembeli baru mau membeli suatu produk kalau memang merasa tepat untuk membeli produk yang bersangkutan Artinya produklah yang harus menyesuaikan diriterhadap pembeli, bukan pembeli yang menyesuaikan diri terhadap produk. Melihat kondisi pasar yang sepi pembeli, kemungkinan oleh karena calon konsumen pada saat ini masih merasakan kurang lengkapnya dan bervariasinya produk yang tersedia di pasar kita sehingga merasa enggan dan kurang daya tarik konsumen untuk mencari sesuatu kebutuhannya. Kalau kita bandingkan dengan pasar modern di BSD dan Bintaro sangat ramai dikunjungi oleh pembeli potensial baik dari lingkungan terdekat maupun calon konsumen yang diluar lingkungan misalnya, konsumen yang kebetulan sedang melewati pasar, konsumen tahu keberadaan lokasi pasar atau konsumen yang mencari pasar melalui GPS untuk mencari pasar terdekat untuk memenuhi kebutuhannya. Selain variasi dari produk-produk yang ditawarkan perlu juga disajikan produk barang/jasa yang sifatnya "Unik "yang mungkin tidak ada di pasar lainnya, misalnya untuk kuliner berupa Makanan khas daerah tentu seperti : Sop SumSum tulang sapi dari Sumatera, Sop Konro dari Sulawesi, Minuman es campur Medan, dan lain sebagainya.

Untuk produk pakaian jadi pria/wanita dengan kualitas dan harganya seperti pemasaran dan penjualan di PasarTanah Abang atau Pusat perbelanjaan Thamrin City atau pasar Tasik yang menjual dari UKM pakaian dari daerah Tasik, Bandung dan sebagainya. Jika calon konsumen mendapat informasi dari sarana promosi melalui iklan dan mouth to mouth kemungkinan merupakan daya tarik konsumen untuk datang ke Pasarkita dengan pertimbangan waktu, jarak, biaya, harga dan sarana, mengingat jika di Pasarkita menjual produk, kualitas, harga juga sama atau harga relatif beda tipis dengan pasar lainnya.

Strategi Produk ini perlu dilakukan variasi produk, unik, spesifikasi produk dan harga sama dengan yang dijual dipasar lainnya yang menjadikan pertimbangan konsumen akan mengunjungi dan membeli produk-produk yang ditawarkan di pasarkita Pamulang.

Pada era digital dan pemanfaatan teknologi Informasi banyak produk-produk yang dijual belikan secara " On Line ", jadi keberadaan kios/ Toko dan Ruko saat ini beralih fungsi menjadi stock list dan persediaan produk-produk. Jadi dapat 
dilakukan penjualan produk secara on line dan buka toko sebagai stock list yang menawarkan produk-produk yang diminati masyarakat dan ketersediannya produk yang diinginkan konsumen saat ini.

\section{HARGA (Price)}

Strategi Bauran Pemasaran tentang Harga, bagi sebagian besar masyarakat masih menduduki tempat teratas sebelum ia membeli barang atau jasa. Bagi penjual yang penting bagaimana menetapkan harga yang pantas, terjangkau oleh masyarakat dan tidak merugikan para penjual/ pedagang di pasar.

Masyarakat sekarang ini karena mudahnya informasi harga pasar dan penggunaan sarana media seperti : jaringan Internet, HP android, Komputer, yang dengan mudahnya bisa mengakses informasi harga pasar dari suatu produk. Oleh karena itu penetapan harga produk ( barang dan jasa ) yang ditawarkan harus diperhitungkan berapa besar margin atau keuntungan yang mau diambil penjual. Buatlah harga maksimum dan minimum yang ditawarkan agar dapat bersaing dengan harga produk yang sama di jual dipasar atau tempat lainnya. Jika mau harga dapat bersaing dan menarik bagi calon pembeli, carilah produk- produk dari produsen/ pabrik/ distributor langsung dan tersedianya produk yang diinginkan/dicari konsumen/ produk unik lainnya yang membuat tanpa banyak melalui pedagang perantara. Semakin pendek jalur distribusi dan tanpa perantara kita dapat menjual dengan harga yang menarik bagi calon konsumen. Misalnya menjual toko pakaian jadi, maka cari dari pabrik / produsen konveksi dengan corak dan design terbaru, Jika menjual sepatu dengan mode untuk remaja milenial, maka cari pabrik sepatunya dan jual dengan harga kompetitif di pasaran. Ini akan merupakan daya tarik konsumen untuk membeli produk dengan harga terjangkau dan relatif murah yang berada di Pasarkita Pamulang.

Strategi harga merupakan faktor penting dalam merogoh kocek calon konsumen dan menjadi pertimbangan dari konsumen yang sangat efisiensi dan berhitung teliti dalam membeli produk. Perilaku konsumen dalam pertimbangan harga sangat sensitif dan rasional karena banyak pedagang menjual dengan harga tinggi dari harga pasar sehingga konsumen tidak mau merasa tertipu dari harga yang dibuat dan selalu mencari harga pasar dengan produk dan kualitas yang sama.

Oleh karena itu para pedagang di Pasarkita agar menjual produk dengan harga yang ditetapkan dengan membandingkan pada harga pasar yang berlaku dan mempertimbangkan memperoleh margin yang wajar dan terjangkau oleh calon pembeli dilingkungannya.

\section{TEMPAT/LOKASI (Place)}

Strategi Bauran Pemasaran dalam melihat Tempat/lokasi berusaha dan berdagang agar memperhatikan dalam menyampaikan Produk barang dan jasa dari penjual sampai ke konsumen harus memperhatikan apakah diperlukan saluran distribusi, apakah perlu penyalur, apakah l;angsung dari penjual ke konsumen/ pembeli. Lokasi Pasarkita Pamulang berada pada posisi yang strategis, dimana lokasi/tempat dekat dengan jalan dan transportasi mudah, parkir luas, lingkungan banyak kompleks perumahan dan padat penduduk, dekat kampus dan pertokoan/perkantoran. Kenapa lokasi Pasarkita yang lokasinya strategis ini kondisinya sepi dari pengunjung. Hal ini terjadi karena ada keterkaitan dengan kedua bauran pemasaran diatas, yaitu produk dan harga. Jika kita amati 
dengan banyaknya toko/kios dan Ruko yang belum maksimal beroperasi atau tidak buka, yang akibatnya penjualan produk barang/jasa sedikit dan terbatas serta kurang bervariasi dari apa yang diinginkan dan dibutuhkan calon pembeli. Lokasi/tempatstrategis tetapi variasi produk sedikit dan tidak unik akan membuat pertimbangan dari calon konsumen tidak berminat mengunjungi Pasarkita. Oleh karena itu perlu dipertimbangkan agar pengelola dan Perhimpunan Pedagang pasarkita Pamulang untuk mewajibkan pemilik kios/ Toko/ Ruko dan pedagang retail dilapak-lapak untuk semuanya beroperasi dan menjual produk yang bervariasi dan harga yang kompetitif dibandingkan dengan pasar disekitar/dilingkungannya.

Beberapa bulan ini Perhimpunan Pedagang Pasarkita Pamulang bersama pengelola pasarkita sudah melakukan upaya untuk menarik pemilik kios dan pedagang untuk memberi dispensasi gratis 1 tahun untuk penyewa kios dan hanya bayar tahun kedua. Upaya ini cukup baik dan semoga dapat meningkatkan semangat dan motivasi para pedagang untuk memajukan dan meramaikan pasarkita Pamulang.

Dilain sisi ada perlu dilakukan pendistribusian produk atau barang yang dijual dengan bekerjasama dengan GOJEK dan GRAB untuk memfasilitasi pengiriman dan pendistribusian produk barang dan makanan yang dibeli konsumen dapat dikirim melalui fasilitas OJOL (Ojek On Line ) sehingga penjualan melalui on line dapat tepat waktu dan cepat diterima pembeli.Jadi lokasi atau tempat yang strategis jika tidak didukung dengan tersedianya produk yang beragam dan sesuai kebutuhan konsumen, penetapan harga yang kompetitif dan proses pengiriman barang dagangan atau makanan yang menggunakan fasilitas Ojek On Line (GOJEK atau GRAB ) sehingga dapat diterima konumen tepat waktu, aman dan cepat yang merupakan kualitas pelayanan prima.

\section{PROMOSI (Promotion)}

Strategi Bauran Pemasaran melalui Promosi juga tidak kalah pentingnya dari ketiga bauran diatas, suatu barang atau produk tidak selalu langsung dikenal oleh konsumen baik produk baru maupun produk lama. Oleh sebab itu perlu dilakukan promosi secara efektif, karena promosi itu kegiatannya memperkenalkan dan mengingatkan kembali akan suatu produk, penjualnya maupun pembuatnya.

Pasarkita Pamulang pernah melakukan even-even yang mengundang banyak pengunjung ke lokasi, antara lain pernah melakukan pemasaran batu cincin dan berbagai fasilitas yang terkait dengan penggosokan, pengikatan, penjualan batu mentah dan siap pakai. Mengundang komunitas - komunitas perbatuan baik dalam kota maupun dari luar kota serta dihadiri dari beberapa artis yang senang dan hobi memakai atau koleksi batu cincin. Kegiatan even ini merupakan salah satu promosi bagi keberadaan Pasarkita yang lokasi dan tempatnya strategis dan mudah dijangkau. Dengan adanya kegiatan even tersebut berdampak pada ramainya pengunjung dan sambil membeli beberapa produk yang ditawarkan terutama kuliner dan makanan ringan lainnya. Namun karena beberapa waktu kemudian product life cycle (PLC) dari batu mulai decline dan menurun sangat drastis sehingga sampai saat ini belum tumbuh kembali.

Promosi merupakan komunikasi yang persusif, mengajak, membujuk, meyakinkan calon konsumen untuk mengetahui keberadaan dari pasarkita, produk yang ditawarkan dan bervariasi, harga yang kompetitif, pelayanan prima dan untuk meningkatkan penjualan. 
Pasarkita perlu melakukan promosi dalam jangka pendek untuk memperkenalkan keberadaannya maupun produk apa saja yang dijual serta apakah harga terjangkau dari konsumen terdekatnya. Cara promosi yang efektif dilakukan di pasarkita antara lain : Periklanan, Personal selling, Publisitas, Sales Promotion dan pemanfaatan Tekhnologi atau perangkat jaringan internet (Website) dan via HP (WA, Instagram, Facebook dan lainnya).

Melaui periklanan biasanya lebih mahal biayanya, namun bisa digunakan sarana periklanan yang lebih murah, misalnya: Spanduk, Poster-poster, stiker yang dipasang ditempat yang ramai dilihat dan strategis. Sehingga dapat menimbulkan calon konsumen menjadi : Perhatian, Menarik dan menimbulkan keinginan. Selain itu melalui personal selling dengan cara berkomunikasi secara pribadi dari mulut ke mulut dengan rekan, keluarga, pertemanan, tetangga, komunitas dan kelompok-kelompok potensial. Melalui Publisitas seperti membuat dalam pemberitaan pada suratkabar/ majalah lokal yang mempunyai arti komersil even-even olah raga sehat, pameran dan even-even positif lainnya dengan tempat dan lokasi dari lingkungan dan masyarakat setempat. Dengan banyaknya dan beranekaragam produk-produk yang ditawarkan, lokasi tempat pasarkita yang strategis perlu dilakukan berbagai cara promosi yang efektif secara terencana dan tepat sasaran agar dapat berdampak terhadap ramainya calon konsumen yang berkunjung ke Pasarkita untuk membeli dan memenuhi segala kebutuhannya.

Keberhasilan suatu bisnis dan usaha dalam Pemasaran harus ditunjang dengan berhasilnya memilih Produk yang tepat, Harga yang pantas, saluran distribusi atau Tempat yang baik dan Promosi yang efektif. Keempat variabel dari bauran pemasaran tersebut harus berfungsi secara terpadu yang disebut Pemasaran terpadu (Intergreated Marketing).

Biaya Promosi pada umumnya memerlukan biaya yang relatif tinggi, oleh karena itu perlu keterlibatan dan dukungan oleh P.T Pahala Alam Progress selaku Developer dan Pemda Kotamadya Tangerang Selatan yang diserahkan dalam mengelola pedagang lapak khususnya dan keberadaan Pasarkita di Pamulang. Promosi dapat dilakukan berupa : mengadakan even-even Pemda, Bazar, Pasar Murah, pameran, memanfaatkan sarana informasi Pemda, dan media informasi lainnya yang efektif dalam rangka pengembangan dan memajukan keberadaan Pasarkita. Intinya pelaksanaan promosi harus mendapat support penuh dari developer dan pemda setempat dan bekerjasama dengan Perhimpunan Pedagang Pasarkita Pamulang.

\section{KESIMPULAN :}

Berdasarkan pembahasan, penelitian dan pengamatan yang telah diuraikan pada bagian sebelum dan tersebut diatas, maka dapat ditarik kesimpulan sebagai berikut :

Untuk memajukan dan meramaikan Pasarkita Pamulang perlu dilakukan implementasi strategi bauran pemasaran yang terdiri dari 4 ( empat ) variabel, yaitu: Produk, Harga, Tempat dan saluran distribusi dan Promosi.

Masih banyak terdapat Lapak,kios, toko dan Ruko yang belum beroperasi sehingga terkesan kurang ada aktivitas seperti pasar dan pusat perdagangan lainnya.

Produk barang yang dijual masih terbatas, harga dari beberapa pedagang relatif belum kompetitif, lokasi dan tempat perdagangan strategis namun pengunjung masih sepi, Kegiatan promosi belum optimal karena developer P.T Pahala Alam Progress menyerahkan pengelolaan lapak-lapak pengelolaannya 
kepada pemda Tangerang Selatan sedangkan kegiatan promosi Pasarkita kurang optimal .

\section{G. Daftar Pustaka}

Angelova Biljana \& Jusuf Zekiri. (2011). Measuring Customer Satisfaction with Service Quality, Trust, and Customer Satisfaction on Customers Loyalty. Abac Journal Vol. 29, No. 1,pp. 24-38.

Isriana Nur Hajjah, Johan Rina Selva,, dan Riadi RM. (2017). Pengaruh Kualitas Pelayanan dan Promosi Terhadap Pengambilan Keputusan Konsumen dalam Memilih Sekolah di SD Islam As-Shofa, Universitas Riau. ISSN: 2337-7887.

Kotler Philip \& Gary Amstrong. (2013). Principles Of Marketing, Eisi 5 England: Pearson Education Limited.

Kotler Philip \& Kevin Lane Keller. (2013). Marketing Management, England: Pearson Horizon.

Peter dan Olson. (2009) "Business \& Economics" Jakarta: Raja Grafindo Persada.

Sallis Edward. (2011). Total Quality Management In Education, Manajemen Mutu Terpadu Pendidikan. Alih Bahasa Ahmad Ali Riyadi. Jogjakarta: IRCiSoD.

Schiffman Leon \& Leslie Lazar Kanuk \& Joseph Wisenblit. (2010). Consumer Behavior Tenth Edition, New York: Pearson.

(2008). Perilaku Konsumen. Edisi Ketujuh. Alih Bahasa Zoelkifli Kasip. Jakarta: PT. Indexs.

Siow Natalia. (2013). Kualitas Pelayanan dan Kepercayaan Pengaruhnya Terhadap Keputusan Pembelian Sepeda Motor Suzuki Satria FU 150 Di Kota Manado. Jurnal EMBA Vol. 3, September 2013, Hal.1069-1078.

Sugiyono. (2013). Metode Penelitian Bisnis. Cetakan 17, Penerbit CV Alfabeta, Bandung.

Syafitri Anggia. (20017). Pengaruh kualitas pelayanan, biaya, lokasi, dan promosi terhadap keputusan mahasiswa dalam memilih Fakultas Ekonomi Universitas Musi Rawas.. Jurnal Motivasi. Vol. 2, No. 1

Tjiptono Fandy. (2008). Pemasaran Strategik. Yogyakarta, Penerbit CV Andi Offset.

(2012). Service Management Mewujudkan Layanan Prima. Yogyakarta: CV Andi Offset

.Umar Husein. (2010). Riset pemasaran dan bisnis. Gramedia Pustaka Utama, Jakarta. 